\title{
An up-to-date catalog of available urinary biomarkers for the surveillance of non-muscle invasive bladder cancer
}

\author{
Francesco Soria ${ }^{1,2}$ - Michael J. Droller ${ }^{3} \cdot$ Yair Lotan $^{4} \cdot$ Paolo Gontero $^{2} \cdot$ David D'Andrea $^{1} \cdot$ Kilian M. Gust $^{1}$. \\ Morgan Rouprêt ${ }^{5} \cdot$ Marek Babjuk $^{6,1} \cdot$ Joan Palou $^{7} \cdot$ Shahrokh F. Shariat ${ }^{1,4,8,9}$
}

Received: 11 April 2018 / Accepted: 15 June 2018 / Published online: 21 June 2018

(c) The Author(s) 2018

\begin{abstract}
Objectives With the advent of novel genomic and transcriptomic technologies, new urinary biomarkers have been identified and tested for bladder cancer (BCa) surveillance. To summarize the current status of urinary biomarkers for the detection of recurrence and/or progression in the follow-up of non-muscle invasive $\mathrm{BCa}$ patients, and to assess the value of urinary biomarkers in predicting response to intravesical Bacillus Calmette-Guerin (BCG) therapy.

Methods and materials A medline/pubmed $\odot$ literature search was performed. The performance of commercially available and investigational biomarkers has been reviewed. End points were cancer detection (recurrence), cancer progression, and response to BCG therapy.

Results The performance requirements for biomarkers are variable according to the clinical scenario. The clinical role of urinary biomarkers in the follow-up of non-muscle invasive BCa patients remains undefined. The FDA-approved tests provide unsatisfactory sensitivity and specificity levels and their use is limited. Fluorescence in situ hybridization (FISH) has been shown to be useful in specific scenarios, mostly as a reflex test and in the setting of equivocal urinary cytology. FISH and immunocytology could conceivably be used to assess BCG response. Recently developed biomarkers have shown promising results; upcoming large trials will test their utility in specific clinical scenarios in a manner similar to a phased drug development strategy.

Conclusions Current commercially available urinary biomarker-based tests are not sufficiently validated to be widely used in clinical practice. Several novel biomarkers are currently under investigation. Prospective multicenter analyses will be needed to establish their clinical relevance and value.
\end{abstract}

Keywords Urinary biomarker $\cdot$ Test $\cdot$ Follow-up $\cdot$ Surveillance $\cdot$ Non-muscle invasive bladder cancer $\cdot$ Recurrence

Shahrokh F. Shariat

shahrokh.shariat@meduniwien.ac.at

1 Department of Urology and Comprehensive Cancer Center, Vienna General Hospital, Medical University of Vienna, Waehringer Guertel 18-20, 1090 Vienna, Austria

2 Division of Urology, Department of Surgical Sciences, San Giovanni Battista Hospital, University of Studies of Torino, Turin, Italy

3 Department of Urology, The Mount Sinai Medical Center, New York, USA

4 Department of Urology, University of Texas Southwestern Medical Center, Dallas, USA
5 Department of Urology, Hôpital Pitié-Salpétrière, Assistance Publique-Hôpitaux de Paris Sorbonne Université, Paris, France

6 Department of Urology, Hospital Motol, Second Faculty of Medicine, Charles University, Prague, Czech Republic

7 Department of Urology, Fundació Puigvert, Universidad Autónoma de Barcelona, Barcelona, Spain

8 Department of Urology, Weill Cornell Medical College, New York, USA

9 Karl Landsteiner Institute of Urology and Andrology, Vienna, Austria 


\section{Introduction}

Bladder cancer ( $\mathrm{BCa}$ ) has the highest lifetime cost per patient of all cancers [1]. This is mainly due to the high recurrence rate and the consequent need for close, long-term follow-up based on the patient's risk profile. Follow-up generally consists of regular surveillance cystoscopy and voided urine cytology with periodic upper urinary tract imaging [3]. The intensity and invasiveness of these tests can lead to morbidity, compromise in patients' quality of life, and financial burden [4].

Use of urinary biomarkers could obviate these and potentially either detect disease recurrence before it becomes visually apparent or exclude its presence. Unfortunately, the most used urinary test, cytology, suffers from insufficient reproducibility and robustness to suffice for utility in various clinical scenarios such as surveillance of the most common type of $\mathrm{BCa}$ (low-grade NMIBC) [5, 6]. Recent multicenter studies have also shown a lower sensitivity of cytology for high-grade cancer compared to historical data [7, 8]. Urinary biomarkers in the surveillance setting have three aims: to reduce the frequency of invasive testing while still detecting early disease recurrence (Rec), to exclude the presence of recurrent disease and to detect progression (Prog) in non-muscle invasive bladder cancer (NMIBC) patients and predicting response to therapies [9].

Several urinary biomarkers have been investigated according to these objectives. Six of them have been approved by the FDA in the follow-up of NMIBC patients. However, the trials designed to determine their accuracy were not sufficient to determine their clinical utility. Low positive predictive values due to insufficiently robust specificity have undermined the ability to use them in clinical practice in most settings. Actually, despite urologists can be considered early adopters of new technologies (in this case, of new markers), the ability to maintain innovations is influenced from performances, impact on decision-making and costs [10]. As such, the use of urinary markers in the surveillance of NMIBC remains limited. To overcome these limitations, a new generation of biomarkers has been developed and is currently under investigation, with initial results reported as "promising".

We sought to review the current literature on urinary biomarkers used in the surveillance of NMIBC patients to discuss recent findings through a clinical lens and to create an up-todate reference point.

\section{Methods and materials}

A medline/pubmed@ literature search was performed with different combinations of the terms "urinary biomarker", "bladder cancer", "superficial bladder cancer", "non-muscle invasive bladder cancer", "surveillance", "follow-up", "performance", and "BCG response". No time period restriction was set. Original articles, reviews and editorials were selected based on their clinical relevance. Cited references from selected articles were analyzed to find and include significant papers missed by our search. The performance of commercially available and investigational biomarkers was reviewed. End points were cancer detection $(\mathrm{Rec})$, cancer Prog, and response to BCG therapy.

\section{Performance criteria desired and urinary markers evaluation according to quality of research: general considerations}

The performance of biomarkers depends upon their sensitivity, specificity, positive predictive value (PPV) and negative predictive value (NPV). A marker's predictive value is influenced by the prevalence of the disease in the population. In tumors, the value of urinary markers according to their sensitivity and specificity varies according to specific clinical scenarios and can influence their predictive value. This should be taken into account during the evaluation process.

Furthermore, an evaluation of biomarkers should not overlook their "clinical utility rating". Since the development phases for biomarkers discovery and application are not dissimilar to those of therapeutic drugs, a phased approach evaluation scale has been proposed [11, 12]. This consists of a sequence of consecutive phases that can be summarized as: (1) preclinical exploratory studies; (2) assay development (phase 0); (3) small retrospective series (phase I); (4) independent validation of the accuracy in larger series (phase II); (5) external validation in retrospective/prospective multicenter series and prospective clinical trials (phase III) and (6) post-approval reports (phase IV) [13]. Based on this scale, it is possible to evaluate the current status of biomarker development processes to understand their role in clinical practice.

To date, five urinary tests (NMP22 test kit, NMP22 BladderChek Test, BTA TRAK, BTA stat, and UroVysion) have been approved by the US Food and Drug Administration (FDA) in the detection and surveillance setting, while the $\mathrm{uCyt}+$ test is only approved in the follow-up of NMIBC patients. However, none of them have been broadly implemented in clinical practice. Furthermore, none are recommended in international guidelines [3, 4, 14]. Numerous novel biomarkers have been tested and are currently under development (phase I-II-III). Thus far, they have not been approved by the FDA or other regulative agencies. However, one must also note that many markers are commercially available with no goal to become FDA-approved. There is no requirement to seek FDA approval for use in the US. While it can help with reimbursement from some insurance companies, it does limit the ability to modify the marker by 
either using additional markers in a panel or changing cutpoints. If the marker is already FDA-approved, then all the studies need to be repeated if the marker is modified even in the slightest. This is a roadblock for refining some of the already approved markers.

\section{Urinary biomarkers for the surveillance of bladder cancer patients}

\section{Performance criteria desired}

The performance criteria for urine markers highly depend on the clinical question to be answered. As with any test (laboratory, imaging, etc.), the result of the test depends heavily on the clinical setting. Since the goals for a marker may be different in a low- vs. high-risk patient or in first vs. fifth year of surveillance, the likelihood of cancer (prevalence) and projected use of the urine marker should impact the type of marker and designed performance characteristics.

For example, if the goal is to avoid a cystoscopy when a marker is negative, the marker has to have a very high NPV. This is especially important in high-grade disease, where a missed cancer due to a negative marker test could have a major impact on disease progression. On the other side, markers with a high sensitivity are needed if the tests are used in a setting where an improved detection is needed such as in patients at 3 months after initial TURBT or in those with high-risk disease. There is broad recognition from studies on enhanced cystoscopy that white-light cystoscopy alone can miss disease, especially carcinoma in situ (CIS) so that a marker can help to identify missed cancer. Most marker studies were not designed to biopsy patients with normal cystoscopy, but an abnormal biomarker. As such, it is not clear if an abnormal marker in the setting of a normal white-light cystoscopy implies the presence of cancer. Patients with a positive cytology are usually taken to the operating room for a biopsy and selective upper tract cytology, but that is not the case for positive markers. The concept of anticipatory positives is based on the concern that a marker can detect disease before it is visualized, but it is still not clear if this is clinically useful information [15].

Finally, predicting response to intravesical therapies such as BCG requires different characteristics than simply an improved detection and the role of urinary biomarkers in this setting is unclear so far.

\section{Urinary markers rated according to quality of research-according to phased approach}

The performances of phase III-IV and phase II-III markers are summarized in Table 1.

\section{Phase III-IV markers}

Nuclear matrix protein 22 (NMP22) Nuclear matrix proteins are a structural part of the cell nucleus and provide support for the nuclear shape. A member of this family, NMP22, has been found to be elevated in malignant urothelial cells compared to normal urothelium, and is released in the urine as the result of apoptosis. Two assays have been developed to detect the presence of NMPs in urine. The first, NMP22BC is a quantitative Elisa test; the NMP22 BladderChek is a qualitative point-of-care (POC) test [16].

Table 1 Summary of phase II-IV and phase II-III marker's performances and their actual role in clinical practice for the surveillance of nonmuscle invasive bladder cancer patients

\begin{tabular}{|c|c|c|c|c|c|}
\hline Marker & $\begin{array}{l}\text { Sensitivity } \\
\text { (range, \%) }\end{array}$ & $\begin{array}{l}\text { Specificity } \\
\text { (range, \%) }\end{array}$ & PPV (range, \%) & NPV (range, \%) & Actual role in clinical practice ${ }^{a}$ \\
\hline NMP22 BladderChek & $11-85.7$ & $77-100$ & $18.2-100$ & $61.9-93.9$ & - \\
\hline NMP22 & $24-81$ & $49-100$ & $31-100$ & $60-91$ & - \\
\hline BTA STAT & $40-72$ & $29-96$ & $40-88$ & $38-76.9$ & - \\
\hline BTA Trak & $50-62$ & $68-87$ & 45.4 & 88.4 & - \\
\hline ImmunoCyt & $50-85$ & $62-86$ & $26-72$ & $81-93$ & $\begin{array}{l}\text { Could be used as reflex test in } \\
\text { case of unsuspicious cystos- } \\
\text { copy and equivocal/atypical } \\
\text { cytology }\end{array}$ \\
\hline UroVysion & $13-100$ & $63-100$ & $21-83$ & $67.9-100$ & $\begin{array}{l}\text { Could be used as reflex test in } \\
\text { case of unsuspicious cystos- } \\
\text { copy and equivocal/atypical } \\
\text { cytology }\end{array}$ \\
\hline Cxbladder monitor & $91-93$ & - & - & $96-97$ & - \\
\hline Bladder cancer (UBC) test & $12-80$ & $77.3-97$ & $65.5-71.4$ & $73.9-76.6$ & - \\
\hline
\end{tabular}

$P P V$ positive predictive value, $N P V$ negative predictive value

${ }^{a}$ Based on international guidelines' recommendations 
Independent of the type of test (qualitative or quantitative), a pooled analysis of seven studies with 4384 patients with previously treated $\mathrm{BCa}$ showed a sensitivity and specificity across all studies of $69 \%$ (range 50-85\%) and $81 \%$ (range 46-93\%), respectively [17].

Fourteen studies reported the performance of NMP22 BladderChek while 15 reported on NMP22BC (Table 2). According to a phased approach, NMP22 tests reached phase III (independent confirmation studies). Recently, four marker-comparison studies have been published, reporting low sensitivity rates of the qualitative test in detecting Rec (11-58\%) [7, 18-20]. In contrast, the quantitative NMP22BC test is measured on a continuous scale and then transformed into a dichotomous variable by choosing a cut-off threshold (estimated at $10 \mathrm{ng} / \mathrm{mL}$ ). From a biologic point of view, the use of a cut-off does not make much sense in the context of the continuity that the appearance of this marker represents, and therefore, generally leads to lower overall accuracy. Indeed, NMP22 BladderChek had a very poor sensitivity level for detecting Rec (26\%), which only slightly outperformed that obtained with NMP22BC in the same population [7]. However, in a decision curve analysis, NMP22 was associated with oncological outcomes; it has been suggested that this test could be useful in decision-making between an immediate and delayed cystoscopy, depending on a clinician's threshold to perform a surveillance cystoscopy [21].

The predictive value of the tests has also been evaluated with discordant results. Only few studies have found an association between NMP22 and future events such as Rec and Prog [19, 21, 22].

Bladder tumor antigen (BTA) Bladder tumor antigen (BTA) tests detect the presence of basement membrane factors in the urine, which are released from tumor cells during stromal invasion. The BTA test exists as two assays: a quantitative Elisa-based assay (BTA TRAK) and a qualitative POC test (BTA stat).

Only a small number of studies have investigated the role of BTA tests in the follow-up of patients with NMIBC (Table 3). The majority of these are phase II-III studies, although no study assessed the value of these tests in a decision-making process. Sensitivity and specificity have varied from 54 to $61 \%$ and from 74 to $86 \%$, respectively [23-25]. These measures are affected by the presence of concomitant conditions such as stones and "benign" genitourinary diseases [26]. Moreover, BTA tests have not been associated with future events such as Rec and Prog. Bell et al. compared the performances of different biomarkers and demonstrated that neither BTA STAT nor BTA Trak was associated with recurrence-free (RFS) or progressionfree survival (PFS) [19]. Due to the low sensitivity and high rates of false-positive results, use of BTA tests cannot be recommended for use in clinical routine.

ImmunoCyt/uCyt+ The ImmunoCyt test is an immunocytological assay based on the microscopic detection of tumor cell antigens by immunofluorescence. The ImmunoCyt test measures the immunocytological expression of sulfated mucin-glycoproteins and glycosylated forms of the carcinoembryonic antigen in urine. In patients presenting with painless hematuria, immunocytology improves the diagnostic accuracy of standard predictive models by a clinically and statistically significant margin [27].

Sensitivity and NPV rates of ImmunoCyt vary between $62-85 \%$ and $74-93 \%$, respectively (Table 4). In 942 patients, Mian et al. found that the sensitivity increased with pathologic grade (79.3\% for G1, 84.1\% for G2 and $92.1 \%$ for G3 tumors) [28]. In a prospective study, Bell et al. found no association of ImmunoCyt with either RFS or PFS [19]. The test is performed under microscopy and requires trained and experienced pathologists. Interobserver variability has been found to be a major drawback. The limited evidence of its benefit led to infrequent usage of the test [16].

UroVysion (FISH) UroVysion is a multicolor fluorescence in situ hybridization (FISH) containing probes to the centromeres of chromosomes 3, 7, 17 and the 9p21 locus (P16 tumor-suppressor gene). Sensitivity and specificity rates in detecting Rec vary from 13 to $94 \%$ and from 63 to $100 \%$, respectively (Table 5).

Despite this high variance in performance, several studies have suggested a clinical utility of FISH in specific clinical scenarios. Seideman et al. investigated the role of FISH in patients with previous $\mathrm{BCa}$ who presented at follow-up with both negative cytology and cystoscopy. In such cases, FISH was able to anticipate disease Rec at a median follow-up of 26 months; mean time to Rec was 12.6 months in patients who were FISH positive compared to 17.9 months in those with negative FISH $(p=0.03)$ [15].

Another scenario for its use is the presence of an unsuspicious cystoscopy and equivocal/atypical cytology or in patients with abnormal cystoscopy, in which the presence of cancer is not clear. In these patients, FISH could be used as a reflex test to adjudicate the significance of these findings [14]. Two prospective studies have evaluated the role of FISH in the setting of atypical cytology or cystoscopy [29]. In these studies, a positive FISH had a high PPV and led to the recommendation to consider biopsy, upper tract imaging or close cystoscopic re-evaluation. Schlomer et al. reported a sensitivity and NPV of 100\% [30]. In fact, based on these and other studies, the guidelines specifically recommend the use of a urine marker in this setting [31].

In terms of the predictive role of FISH, Kim et al. [32] reported the predictive role of FISH in NMIBC patients with 
Table 2 List of studies investigating the performances of NMP22 tests in surveillance setting in non-muscle invasive bladder cancer patients

\begin{tabular}{|c|c|c|c|c|c|c|}
\hline Marker & $\begin{array}{l}\text { Author (year) refer- } \\
\text { ence }\end{array}$ & Study design & No. of patients & Sensitivity (\%) & Specificity (\%) & Other end points \\
\hline \multirow{14}{*}{$\begin{array}{l}\text { NMP22 } \\
\text { Blad- } \\
\text { derChek }\end{array}$} & $\begin{array}{l}\text { Aguilera Tubet } \\
\text { (2005) [65] }\end{array}$ & $\begin{array}{l}\text { Cohort/marker com- } \\
\text { parison }\end{array}$ & 88 & 28 & 93.55 & - \\
\hline & $\begin{array}{l}\text { Grossman (2006) } \\
\text { [66] }\end{array}$ & Cohort prospective & 668 & 49.5 & 87.3 & NPV $90.5 \%$ \\
\hline & Kumar (2006) [67] & Cohort & 131 & 85 & 77 & $\begin{array}{l}\text { PPV } 67.2 \%, \text { NPV } \\
\quad 90.4 \%\end{array}$ \\
\hline & $\begin{array}{l}\text { Gonzalo Rodriguez } \\
\text { (2008) [68] }\end{array}$ & Cohort & 109 & 25 & 91.1 & $\begin{array}{l}\text { PPV } 18.2 \%, \text { NPV } \\
93.9 \%\end{array}$ \\
\hline & Gupta (2009) [69] & Cohort prospective & 145 & 85.7 & 77.5 & $\begin{array}{l}\text { PPV } 70.6 \% \text {, NPV } \\
89.6 \% \text {. association } \\
\text { with rec }\end{array}$ \\
\hline & Kundal (2010) [70] & Cohort & 115 & 81.3 & 92 & - \\
\hline & Choi (2010) [71] & Cohort & 262 & 72.7 & 91.7 & - \\
\hline & Hwang (2011) [72] & Cohort & 597 & 22.6 & 97.9 & - \\
\hline & Coskuner (2012) [73] & Cohort & 95 & 44.4 & 98.4 & PPV $80 \%$, NPV $92.6 \%$ \\
\hline & Önal (2015) [74] & Cohort/case control & 65 & 85.4 & 76.5 & - \\
\hline & Yafi (2015) [17] & $\begin{array}{l}\text { Marker-comparison } \\
\text { prospective }\end{array}$ & 109 & 58 & 85 & - \\
\hline & Bell (2016) [18] & $\begin{array}{l}\text { Marker-comparison } \\
\text { prospective }\end{array}$ & 91 & - & - & $\begin{array}{l}\text { Association with RFS } \\
\text { and PFS }\end{array}$ \\
\hline & Lotan (2017) [7] & $\begin{array}{l}\text { Marker-comparison } \\
\text { prospective }\end{array}$ & 803 & 11 & - & NPV $86 \%$ \\
\hline & Pichler (2017) [19] & $\begin{array}{l}\text { Marker-comparison } \\
\text { prospective }\end{array}$ & 75 & 12.9 & 100 & $\begin{array}{l}\text { PPV } 100 \%, \text { NPV } \\
\quad 61.9 \%\end{array}$ \\
\hline \multirow[t]{15}{*}{ NMP22 } & Serretta (1998) [75] & Cohort & 137 & 71 & 61 & PPV $44.7 \%$, NPV $83 \%$ \\
\hline & Witjes (1998) [76] & Cohort & 50 & 75 & 82 & PPV 56\%, NPV 91\% \\
\hline & Serretta (2000) [77] & $\begin{array}{l}\text { Marker-comparison } \\
\text { prospective }\end{array}$ & 179 & 74 & 55 & PPV $42.2 \%$, NPV $83 \%$ \\
\hline & Chahal (2001) [78] & Cohort & 115 & 24 & 92 & PPV 33\%, NPV 87\% \\
\hline & $\begin{array}{l}\text { Giannopoulos (2001) } \\
\text { [79] }\end{array}$ & $\begin{array}{l}\text { Marker-comparison } \\
\text { prospective }\end{array}$ & 95 & 56 & - & - \\
\hline & Shariat (2004) [80] & Cohort/case control & $302 / 42$ & $\begin{array}{l}66 \text { (cut-off } 6.5 \mathrm{U} / \mathrm{ml}) \\
54 \text { (cut-off } 10 \mathrm{U} / \\
\mathrm{ml})\end{array}$ & $\begin{array}{l}73 \text { (cut-off } 6.5 \mathrm{U} / \mathrm{ml} \text { ) } \\
85 \text { (cut-off } 10 \mathrm{U} / \\
\mathrm{ml})\end{array}$ & $\begin{array}{l}\text { Prediction of } \mathrm{BCa}(\mathrm{OR} \\
1.5)\end{array}$ \\
\hline & $\begin{array}{l}\text { Aguilera Tubet } \\
\text { (2005) [65] }\end{array}$ & $\begin{array}{l}\text { Cohort/marker com- } \\
\text { parison }\end{array}$ & 88 & 35 & 80.3 & - \\
\hline & Lahme (2005) [81] & $\begin{array}{l}\text { Cohort/case control } \\
\text { prospective }\end{array}$ & $164 / 64$ & 62 & 65.9 & - \\
\hline & Kibar (2006) [82] & $\begin{array}{l}\text { Cohort/case control } \\
\text { marker comparison }\end{array}$ & $60 / 30$ & 73 & 89.7 & - \\
\hline & Raina (2008) [83] & $\begin{array}{l}\text { Cohort (atypical } \\
\text { cytology) }\end{array}$ & 71 & 81 & 89.3 & PPV 92\%, NPV 76\% \\
\hline & Mansoor (2008) [84] & Cohort & 94 & 45 & 100 & PPV $100 \%$, NPV $87 \%$ \\
\hline & $\begin{array}{l}\text { Horstmann (2009) } \\
\text { [85] }\end{array}$ & Cohort & 221 & 68 & 49 & PPV 57\%, NPV 60\% \\
\hline & Shariat (2011) [20] & $\begin{array}{l}\text { Cohort (negative } \\
\text { cytology) }\end{array}$ & 2222 & - & - & $\begin{array}{l}\text { Association with Rec } \\
\text { and Prog }\end{array}$ \\
\hline & Doğan (2013) [86] & Cohort & 49 & 33 & 76 & PPV $31 \%$, NPV $78 \%$ \\
\hline & Lotan (2017) [7] & $\begin{array}{l}\text { Marker-comparison } \\
\text { prospective }\end{array}$ & 803 & 26 & - & NPV $86 \%$ \\
\hline
\end{tabular}

$P P V$ positive predictive value, $N P V$ negative predictive value, $R e c$ recurrence, $P r o g$ progression, $R F S$ recurrence-free survival, $P F S$ progressionfree survival 
Table 3 List of studies investigating the performances of BTA tests in surveillance setting in patients with non-muscle invasive bladder cancer

\begin{tabular}{|c|c|c|c|c|c|c|}
\hline Marker & Author (year) reference & Study design & No. of patients & $\begin{array}{l}\text { Sensitivity } \\
(\%)\end{array}$ & Specificity (\%) & Other end points \\
\hline \multirow[t]{12}{*}{ BTA STAT } & Sarosdy (1995) [25] & $\begin{array}{l}\text { Cohort prospective/case- } \\
\text { control (separate) }\end{array}$ & $499 / 564$ & 40 & 96 & - \\
\hline & Ianari (1997) [87] & Cohort & 75 & 54 & 91 & - \\
\hline & Leyh (1997) [88] & Cohort prospective & 164 & 54 & 92 & - \\
\hline & Hargreave (1997) [89] & Cohort prospective & 272 & 58 & 86 & - \\
\hline & Sarosdy (1997) [90] & $\begin{array}{l}\text { Cohort retrospective/case- } \\
\text { control (separate) }\end{array}$ & $220 / 550$ & 67 & $29-95$ & - \\
\hline & Serretta (2000) [77] & $\begin{array}{l}\text { Marker-comparison retro- } \\
\text { spective }\end{array}$ & 179 & 57 & 62 & PPV $40 \%$, NPV $76.9 \%$ \\
\hline & Giannopoulos (2001) & $\begin{array}{l}\text { Marker-comparison pro- } \\
\text { spective }\end{array}$ & 95 & 72 & - & - \\
\hline & Sarosdy (2002) [91] & $\begin{array}{l}\text { Cohort/case-control (sepa- } \\
\text { rate) }\end{array}$ & 438 & 50 & - & - \\
\hline & Lokeshwar (2002) [24] & Cohort prospective & 26 & 61 & 74 & PPV 88\%, NPV 38\% \\
\hline & Raitanen (2008) & Cohort prospective & 501 & 56 & 86 & - \\
\hline & Yafi (2015) [17] & $\begin{array}{l}\text { Marker-comparison pro- } \\
\text { spective }\end{array}$ & 109 & 61 & 78 & - \\
\hline & Bell (2016) [18] & $\begin{array}{l}\text { Marker-comparison pro- } \\
\text { spective }\end{array}$ & 91 & - & - & $\begin{array}{l}\text { No association with RFS } \\
\text { or PFS }\end{array}$ \\
\hline \multirow[t]{6}{*}{ BTA Trak } & $\begin{array}{l}\text { Gutierrez Banoz (1999) } \\
\text { [92] }\end{array}$ & Cohort & 122 & 61 & 87 & - \\
\hline & Serretta (2000) & $\begin{array}{l}\text { Marker-comparison retro- } \\
\text { spective }\end{array}$ & 179 & 62 & 79 & PPV $45.4 \%$, NPV $88.4 \%$ \\
\hline & Sarosdy (2002) [91] & $\begin{array}{l}\text { Cohort/case-control (sepa- } \\
\text { rate) }\end{array}$ & 438 & 50 & - & - \\
\hline & $\begin{array}{l}\text { Fernandez Gomez } \\
\text { (2002) [93] }\end{array}$ & Cohort & $\begin{array}{l}\text { Unknown (700 } \\
\text { samples) }\end{array}$ & 62 & 68 & - \\
\hline & Babjuk (2008) [22] & Cohort prospective & 88 & 54 & 84 & - \\
\hline & Bell (2016) [18] & $\begin{array}{l}\text { Marker-comparison pro- } \\
\text { spective }\end{array}$ & 91 & - & - & $\begin{array}{l}\text { No association with RFS } \\
\text { or PFS }\end{array}$ \\
\hline
\end{tabular}

$P P V$ positive predictive value, $N P V$ negative predictive value, $R F S$ recurrence-free survival, $P F S$ progression-free survival

Table 4 List of studies investigating the performances of ImmunoCyt test in surveillance setting in non-muscle invasive bladder cancer patients

\begin{tabular}{llllll}
\hline Author (year) reference & Study design & No. of patients & $\begin{array}{l}\text { Sensitivity } \\
(\%)\end{array}$ & $\begin{array}{l}\text { Specificity } \\
(\%)\end{array}$ & Other end points \\
\hline Vriesema (2001) [94] & Cohort & 86 & 50 & 73 & PPV 39\%, NPV 81\% \\
Pfister (2003) [95] & Cohort & 458 & 70 & 82 & - \\
Tetu (2005) [96] & Cohort & 904 & 74 & 62 & PPV 26\%, NPV 93\% \\
Messing (2005) [97] & Cohort & 341 & 81 & 75 & - \\
Lodde (2006) [98] & Cohort & 195 & 84 & 86 & PPV 63\%, NPV 92\% \\
Mian (2006) [27] & Marker-guided prospective & 942 & 85 & 72 & - \\
Sullivan (2009) [99] & Cohort & 100 & 76 & 63 & PPV 43\%, NPV 88\% \\
Horstmann (2009) [85] & Cohort & 221 & 73 & 62 & PPV 72\%, NPV 74\% \\
Yafi (2015) [17] & Marker-comparison prospective & 109 & 62 & 79 & - \\
Bell (2016) [18] & Marker-comparison prospective & 91 & - & - & No association with RFS or PFS
\end{tabular}

$P P V$ positive predictive value, $N P V$ negative predictive value, $R F S$ recurrence-free survival, $P F S$ progression-free survival 
Table 5 List of studies investigating the performances of UroVysion test in surveillance setting in non-muscle invasive bladder cancer patients

\begin{tabular}{|c|c|c|c|c|c|}
\hline Author (year) reference & Study design & No. of patients & Sensitivity (\%) & Specificity (\%) & Other end points \\
\hline Sarosdy (2002) [91] & Cohort/case-control (separate) & 438 & 71 & 94 & - \\
\hline Varella-Garcia (2004) [100] & Cohort & 19 & 87 & 100 & - \\
\hline Pycha (2004) [101] & Cohort & 49 & 35 & 86 & - \\
\hline Kipp (2005) [102] & Cohort prospective & 37 & 48 & 100 & - \\
\hline Bergmann (2007) [103] & Cohort & 41 & 77 & 93 & PPV $83 \%$, NPV $90 \%$ \\
\hline Moonen (2007) [104] & Cohort & 105 & 39 & 90 & - \\
\hline Yoder (2007) [105] & Cohort, reflex (negative cytology) & 249 & 73 & 87 & - \\
\hline Gudjónsson (2008) [106] & Cohort & 159 & 30 & 95 & - \\
\hline Sullivan (2009) [99] & Cohort & 100 & 13 & 90 & PPV 33\%, NPV $72 \%$ \\
\hline Horstmann (2009) [85] & Cohort & 221 & 76 & 63 & PPV $68 \%$, NPV $71 \%$ \\
\hline Karnwal (2010) [107] & Cohort & 59 & 63 & 65 & - \\
\hline Schlomer (2010) [29] & $\begin{array}{l}\text { Cohort (atypical cytology and nega- } \\
\text { tive/equivocal cystoscopy) }\end{array}$ & 73 & 100 & 67 & PPV $21 \%$, NPV $100 \%$ \\
\hline Fritsche (2011) [108] & Cohort (all HG) & 25 & 94 & 93 & PPV 76\%, NPV 99\% \\
\hline Youssef (2012) [109] & Cohort, reflex (negative cytology) & 142 & 23 & 94 & PPV $40 \%$, NPV $88.5 \%$ \\
\hline $\operatorname{Kim}(2014)[31]$ & $\begin{array}{l}\text { Cohort (negative cystoscopy, suspi- } \\
\text { cious cytology) }\end{array}$ & - & - & - & Association with Rec \\
\hline Sideman (2015) [14] & $\begin{array}{l}\text { Cohort, reflex (negative cystology and } \\
\text { negative cystoscopy) }\end{array}$ & 664 & 56 & 67 & PPV $54.8 \%$, NPV $67.9 \%$ \\
\hline Lotan (2017) [7] & Marker-comparison prospective & 157 & 33 & - & NPV $92 \%$ \\
\hline
\end{tabular}

$P P V$ positive predictive value, $N P V$ negative predictive value, $R e c$ recurrence

negative cystoscopy and suspicious cytology in which positive FISH was a significant predictor of Rec (HR 2.35; $95 \%$ CI 1.42-3.90, $p=0.001)$ in multivariable analysis and for Prog (HR 3.01; 95\% CI, 1.10-8.21, $p=0.03$ ) in univariable analysis. It has further been shown that the decision to omit bladder biopsy because of negative UroVysion in patients with atypical cytology and negative or equivocal cystoscopy was cost-effective and may allow reduction of unnecessary adverse events [33].

\section{Phase II-III markers}

Cxbladder monitor Studies investigating the performance of this test are listed in Table 6. The Cxbladder Monitor test is based on the detection of four mRNAs that are significantly increased in the urine of $\mathrm{BCa}$ patients and of another mRNA that is associated with non-malignant conditions, included to reduce false-positive results. This marker panel was designed to optimize sensitivity. While this has improved test performance for this goal with reported sensitivity and NPV of 93 and 97\%, respectively, it does come at the cost of a low specificity [34]. Sensitivity reached $95 \%$ in recurrent disease with high risk of Prog, and false-negative findings were reported in only $1.5 \%$ of cases. These data have been successfully externally validated [7]. This test may allow clinicians to postpone or avoid cystoscopy in patients under surveillance, who are at low risk of Rec. This might lower the cost and potential morbidity while improving quality of life in these patients.

Bladder cancer test (UBC test) The Bladder Cancer Test (UBC) is available in two different assays. One is a quantitative, ELISA-based assay (UBC IRMA) while the other is a qualitative POC-based assay (UBC Rapid). Both of these detect the presence of cytokeratins 8 and 18 in the urine which play an active role in tumor invasion. Sensitivity and specificity rates vary from 12 to $80 \%$ and from 77 to $92 \%$, respectively. When performed in combination with cytology, UBC has been reported to increase the overall sensitivity to $77.4 \%$ while decreasing its specificity [20]. Conversely to the other markers UBC is a point-of-care test, with results available within $10 \mathrm{~min}$, and therefore, with possible and incontrovertible clinical advantages. However, the clinical utility of the UBC test in the follow-up of NMIBC patients remains unconvincing.

\section{Phase I-II markers}

XPERT BC monitor The XPERT Bladder Cancer (BC) Monitor is an mRNA-based urinary marker test developed for BCa surveillance. It measures the levels of five different target mRNAs (ABL1, CRH, IGF2, UPK1B and ANXA10) by real-time PCR. These mRNAs are related to cell proliferation and survival, signal transduction and response to neuroendocrine stress. Advantages of the test are mainly related 
Table 6 List of studies investigating the performance of CXbladder monitor and UBC tests in surveillance setting in patients with non-muscle invasive bladder cancer

\begin{tabular}{|c|c|c|c|c|c|c|}
\hline Marker & $\begin{array}{l}\text { Author (year) refer- } \\
\text { ence }\end{array}$ & Study design & No. of patients & Sensitivity (\%) & Specificity (\%) & Other end points \\
\hline \multirow[t]{2}{*}{ CXbladder monitor } & Lotan (2017) [7] & $\begin{array}{l}\text { Marker-comparison } \\
\text { prospective }\end{array}$ & 803 & 91 & - & NPV 96\% \\
\hline & Kavalieris (2017) [33] & Cohort prospective & 763 & 93 & - & NPV $97 \%$ \\
\hline \multirow{5}{*}{$\begin{array}{l}\text { Bladder cancer (UBC) } \\
\text { test }\end{array}$} & Kibar (2006) [82] & Cohort/case-control & $60 / 30$ & 60 & 92.3 & - \\
\hline & $\begin{array}{l}\text { Giannopoulos (2001) } \\
\text { [79] }\end{array}$ & $\begin{array}{l}\text { Marker-comparison } \\
\text { prospective }\end{array}$ & 95 & 80 & - & - \\
\hline & Babjuk (2008) [22] & Cohort prospective & 88 & 12 & 97 & - \\
\hline & Pichler (2017) [19] & $\begin{array}{l}\text { Marker-comparison } \\
\text { prospective (UBC } \\
\text { qualitative) }\end{array}$ & 75 & 61.3 & 77.3 & $\begin{array}{l}\text { PPV } 65.5 \%, \text { NPV } \\
73.9 \%\end{array}$ \\
\hline & Pichler (2017) [19] & $\begin{array}{l}\text { Marker-comparison } \\
\text { prospective (UBC } \\
\text { quantitative) }\end{array}$ & 75 & 64.5 & 81.8 & $\begin{array}{l}\text { PPV } 71.4 \%, \text { NPV } \\
76.6 \%\end{array}$ \\
\hline
\end{tabular}

$P P V$ positive predictive value, $N P V$ negative predictive value

to its rapidity $(<2$ min of hands-on sample preparation and total PCR time of around $90 \mathrm{~min}$ ). The first results of XPERT BC test have been recently reported [35]. In this study, a total of 155 urine samples of 140 patients with history of NMIBC were collected during routine follow-up. The test showed to be significantly superior to urinary cytology in terms of overall sensitivity (84 vs 33\%) and NPV (93 vs $76 \%$ ), while overall specificity did not differ between tests (91 vs 94\%). Moreover, while the sensitivity of the XPERT BC Monitor was $100 \%$ in patients with high-grade tumors, it remains relatively high (compared to cytology) also in patients with low-grade disease (77\%). These findings are encouraging and call for prospective trials to go ahead in the test's validation process.

Soluble FAS Soluble FAS (sFAS) is an antiapoptotic protein released by $\mathrm{BCa}$ cells, protecting them from host antitumor activity. They are released in serum and urine, where they can be detected and measured by ELISA. Svatek et al. measured sFAS levels in 188 patients at risk for BCa Rec [36]. Higher levels of sFAS were associated with tumor stage $\geq T 1$, positive urinary cytology results and higher NMP22 levels. sFAS was more specific than NMP22 and was able to predict the presence of $\mathrm{BCa}$ in patients with negative cytology, suggesting that sFAS may be helpful as a complement to cytology. On multivariable analysis, sFAS levels predicted the presence of tumor (OR 3.1, CI 95\% 1.65.9) and invasive stage (OR 3.7, CI 95\% 1.3-10.9). These results were confirmed by Yang and colleagues who found that sFAS levels were an independent predictor of RFS (HR 1.4, 95\% CI 1.1-1.9) [37]. However, the sFAS assay still needs to be refined and standardized prior to its introduction into clinical care. Moreover, further large, prospective, multicenter phase III trials are also needed.
Hyaluronic acid Hyaluronic acid (HA) is a non-sulfated glycosaminoglycan that is involved in cell adhesion and proliferation, promotes tumor metastasis, and has been shown to be elevated in a variety of tumors. It is degraded by hyaluronidase enzyme (HAase) into small fragments that promote angiogenesis [16]. HA and HAase have been found to be elevated in the urine of BCa patients; they are measured with ELISA and RT-qPCR [38]. Lokeshwar et al. [25] performed the HA-HAase test on 225 urine samples from 70 BCa patients. Sensitivity, specificity, PPV and NPV were 91, 70, 92 and 67\%, respectively. In this study, the HA-HAase test demonstrated superior performance compared to the BTA Stat test. However, to date, this is the only published study focusing on the role of the HA test in the follow-up of NMIBC patients.

Survivin Survivin is an antiapoptotic protein that is almost exclusively expressed by malignant epithelium, which inhibits apoptosis, promotes cell proliferation, and induces/ enhances angiogenesis. Shariat et al. [39] evaluated levels of survivin and NMP22 in voided urine samples from 117 BCa patients undergoing cystoscopy and 92 controls. Survivin had superior sensitivity (64\%), specificity (93\%), PPV (92\%) and NPV (67\%) compared to both NMP22 and urine cytology. Moreover, higher levels of survivin were associated with an increased risk of more advanced histologic grades [40]. While these findings are promising, this is the only published study evaluating the role of urinary survivin in the follow-up of NMIBC. Moreover, due to its low linearity, the assay remains experimental and requires further development and standardization.

Telomerase Telomerase is a ribonucleoprotein that synthesizes telomeres at the ends of chromosomes, thus ensur- 
ing genome stability. Several tumors, including $\mathrm{BCa}$, show telomerase hyperactivity that protects the chromosomes of cancer cells and thereby produces potential immortality [16]. One study explored the role of telomerase in patients with previous diagnosis of NMIBC [41]. Brems et al. measured levels of telomerase in 123 patients with $\mathrm{BCa}$ (12 incident cancers and 111 follow-up visits) and found that higher telomerase levels were associated with Rec (sensitivity and specificity of 62 and $84 \%$, respectively), and that combining telomerase with cytology led to an increased sensitivity, but to a decreased specificity in diagnosis when compared to cytology alone. The lack of specificity of telomerase activity makes it a biomarker of little value with a high falsepositive rate. Moreover, assays for telomerase still need to be standardized and validated.

Fibroblast growth factor receptor 3 (FGFR3) and methylation biomarkers About $70 \%$ of low-grade NMIBC has been found to harbor a mutation in the fibroblast growth factor three (FGFR3) gene [42]. Since this mutation seems to be able to identify a subgroup of patients with good prognosis [43], its analysis could serve as biomarker not only for the detection of recurrence during follow-up of low-grade cancers, but also to identify patients with a low risk of progression. Zuiverloon et al. determined the FGFR3 mutation status on 200 low-grade NMIBC patients [44]. The sensitivity of the assay for the detection of concomitant recurrence was $58 \%$, while a $F G F R 3$-positive test was associated with a 3.8-fold higher risk to have a recurrence during follow-up.

Several studies have explored the role of different DNA methylation genes as urinary biomarkers in the surveillance setting. Actually, changes in DNA methylation are stable, tend to occur early during carcinogenesis and can be detected in cells released in urine. Methylation biomarkers' performance seems to be highly variable depending on the studies. Su et al. analyzed the DNA methylation levels of six markers in 368 urine samples from 90 patients with NMIBC and reported a sensitivity and specificity of 89 and $97 \%$, respectively [45]. Similar findings were reported for other methylation markers [46, 47]. On the contrary, other studies did not confirm these promising findings: Abern et al. developed a PCR assay based on the methylation status of TWIST1 and NID2. In a prospective surveillance trial, a relatively low sensitivity of $58 \%$ and specificity of $66 \%$ were reported [48]. Based on these results, methylation gene panels are, to date, far away to be implemented in routine clinical practice.

The combination of FGFR 3 status and methylation biomarkers has been tested with promising results initially. Beukers et al. investigated the role of $F G F R 3$ and of the methylation genes TERT and $O T X 1$ in 977 NMIBC patients [49]. The combination of the three assays detected $57 \%$ of Rec with a specificity of $59 \%$. The diagnostic value of FGFR3 was limited in HG tumors, reflecting the lower percentage of its mutation in this subgroup of patients. FGFR3 mutation was found to predict Rec over time: false-positive urine samples from patients with FGFR3 mutations were followed by a recurrence within 2 years in $73 \%$ of patients. Similarly, FGFR3 mutation in combination with a 3-plex methylation assay was found to have a sensitivity of $79 \%$ and a specificity of $77 \%$ in detection of a tumor recurrence [50]. Finally, combining FGFR3 mutational status with methylation measurement of a set of DNA methylation markers (HS3ST2, SEPTIN9 and SLIT2) led to a sensitivity/specificity/NPV of $94.5 / 75.9 / 98.5 \%$, respectively, for detection of a recurrent tumor [51]. Combined analyses of FGFR3 mutation and DNA methylation markers could be valuable for risk stratification of patients with NMIBC and for surveillance setting, providing the basis for a promising non-invasive urinary test.

Angiogenesis markers Vascular endothelial growth factor (VEGF) is associated with tumor angiogenesis and is secreted in urine by $\mathrm{BCa}$ cells. It is detectable and measurable with ELISA. High levels of urinary VEGF have been related to poor RFS in patients with previous NMIBC [52]. However, these preliminary data and the role of VEGF in a surveillance setting remain to be confirmed.

Others DNA microsatellites are short tandem DNA repeats resulting from a failure of DNA mismatch repair and are, therefore, involved in tumor cell transformation. They have been studied as urinary markers [53]. However, the low sensitivity and specificity (58 and 73\%, respectively) are not sufficient to recommend their implementation in clinical practice.

Finally, several other investigational biomarkers such as Ki-67, Fibronectin, CD44 antigen and BCa cell metabolites have been suggested to be related to the presence of $\mathrm{BCa}$ and have been studied in $\mathrm{BCa}$ detection [54]. However, their role in $\mathrm{BCa}$ surveillance remains uninvestigated or preliminary.

\section{Urinary biomarkers for the prediction of BCG response}

\section{Performance criteria desired}

The goal of urine markers in this specific scenario is to predict whether BCG treatment will be effective and to monitor its effectiveness.

\section{Urinary markers rated according to quality of research-according to a phased approach}

BCG efficacy appears to depend on the ability to generate an appropriate immune response, including mainly CD4 + T 
cells and CD8 + cytotoxic T lymphocytes (CTLs) [55]. The therapeutic antitumor effect of intravesical BCG involves the interactive activity of urothelial cells (including $\mathrm{BCa}$ cells) and cells of the immune system. BCa cells are able to internalize BCG through phagocytosis and macropinocytosis. After this event, BCa cells directly secrete immune-activating effectors such as chemokines and cytokines (i.e., IL-6, IL-8, GM-CSF and TNF). Moreover, BCa cells are functioning antigen-presenting cells, presenting $\mathrm{BCG}$ antigens to $\mathrm{CD} 4+\mathrm{T}$ cells. $\mathrm{BCa}$ cells are finally killed by cytotoxic immune cells, secretion of soluble factors and the direct action of BCG [56].

\section{Phase III-IV markers}

According to AUA/SUO Guidelines, "clinicians may use biomarkers to assess the response to intravesical BCG (UroVysion ${ }^{\circledR}$ FISH) and adjudicate equivocal cytology (UroVysion ${ }^{\circledR}$ FISH and ImmunoCyt ${ }^{\circledR}$ )" [14]. UroVysion, performed 6 weeks after the last BCG instillation, was reported to predict BCG failure (either disease persistence or Rec), both in patients with positive urine cytology and in those with non-definitive cytology [57]. Abnormal results obtained from serial measurements of UroVysion at baseline (before BCG), at 6 weeks (before the last BCG induction cycle) and at 3 months (before the first surveillance cystoscopy) were significantly associated with Rec and Prog. The term "molecular BCG failure" was proposed to define those patients with abnormal FISH results and negative first cystoscopy [58]. However, this concept remains to be validated.

\section{Phase II-III markers}

The presence and levels of BCG-induced cytokines in urine can be measured and might predict the clinical response to BCG. Kamat et al. [59] measured levels of 12 urinary cytokines and calculated changes from baseline during BCG treatment, developing a nomogram, based on nine inducible cytokines [IL-2, IL-8, IL-6, IL-1ra, IL-10, IL12(p70), IL-12(p40), TRAIL, and TNF- $\alpha$ ] that could predict Rec with an accuracy of 85.5\% (95\% CI 77.9-93.1). Previously, several studies had focused on the role of urinary IL-2 levels in patients treated with BCG [60-62]. High levels of IL-2 in urine after BCG administration were associated with increased risk of Rec. Similarly, elevated urinary levels of IL-8 and IL-18 after BCG therapy predicted RFS [63]. At a cut-off threshold of $112 \mathrm{pg} / \mathrm{mL}$, IL- 8 measured $2 \mathrm{~h}$ after BCG instillation predicted Rec with a sensitivity of $53 \%$, specificity of $89 \%$, PPV of $73 \%$, and NPV of $77 \%$ [64]. Finally, the IL-6/IL-10 ratio was able to predict BCG response and RFS in patients at intermediate risk with a sensitivity and specificity of 83 and $76 \%$, respectively [65].

The suggested role of biomarkers involved in the prediction of BCG response is summarized in Table 7.

\section{Conclusions}

Many urinary biomarkers have been evaluated to predict $\mathrm{Rec}$ and/or Prog in the follow-up of NMIBC patients. Current commercially available urinary biomarker tests provide inadequate performance and are neither routinely used nor recommended in clinical practice. However, some of them could be useful in specific clinical scenarios such as a negative cystoscopy and inconclusive/suspicious urinary cytology. Moreover, preliminary results have shown that urinary markers such as FISH might be useful to predict BCG response. Despite this, prospective well-controlled trials are lacking and are needed to provide high-evidence data before these tests can be integrated into clinical use.

Several new biomarkers have recently been developed and are currently under investigation. Despite encouraging

Table 7 List of biomarkers predicting response to intravesical BCG in patients with non-muscle invasive bladder cancer

\begin{tabular}{|c|c|c|c|c|}
\hline Urinary biomarker & Patients & Outcome investigated & Magnitude of effect & Ref. \\
\hline IL-2 & CIS & RFS & HR $0.368 ; 95 \%$ CI, 0.029-0.895 & {$[60]$} \\
\hline IL-6/IL-10 & High-risk NMIBC & RFS & HR $4.09 ; 95 \%$ CI $2.59-6.28$ & [64] \\
\hline IL-8 & Primary NMIBC & Recurrence & $\begin{array}{l}\text { Sensitivity } 53.3 \% \text {, specificity } 88.5 \% \text {, PPV } \\
72.7 \% \text {, NPV } 76.7 \%\end{array}$ & [63] \\
\hline IL-18 & NMIBC & Recurrence & $\begin{array}{l}\text { Different IL-18 level's statistical signifi- } \\
\text { cance in patients with or without recur- } \\
\text { rence }\end{array}$ & {$[62]$} \\
\hline $\begin{array}{l}\text { Nomogram [IL-2, IL-8, IL-6, IL-1ra, IL-10, } \\
\text { IL-12(p70), IL-12(p40), TRAIL, and } \\
\text { TNF- } \alpha]\end{array}$ & $\begin{array}{l}\text { Intermediate- } \\
\text { and high-risk } \\
\text { NMIBC }\end{array}$ & Recurrence & Accuracy $85.5 \%$; 95\% CI 77.9-93.1\% & {$[58]$} \\
\hline UroVysion & NMIBC & Persistence or recurrence & HR 5.6; 95\% CI, 2.5-12.2 & {$[56]$} \\
\hline
\end{tabular}

$H R$ hazard ratio, $C I$ confidence interval, $P P V$ positive predictive value, $N P V$ negative predictive value, $C I S$ carcinoma in situ, $N M I B C$ nonmuscle invasive bladder cancer 
results, their clinical relevance remains to be established. Most of them have not yet gone through all of the necessary phases of marker development and the testing process. However, a renewed interest about biomarkers is growing and it is probable that in the next few years, a generation of new biomarkers will enter into the clinical setting.

\section{Acknowledgements Open access funding provided by Medical Uni-} versity of Vienna.

Author contributions Protocol/project development: SF, DMJ, SSF. Data collection or management: SF, SSF, DMJ, DD, GKM, GP, PJ, BM, RM, LY. Data analysis: SF, DMJ, SSF. Manuscript writing/editing: SF, DMJ, SSF wrote the Manuscript. SF, SSF, DMJ, DD, GKM, GP, PJ, BM, RM, LY edited the Manuscript.

\section{Compliance with ethical standards}

Conflict of interest I certify that all conflicts of interest, including specific financial interests and relationships and affiliations relevant to the subject matter or materials discussed in the manuscript are the following: Shahrokh Shariat owns or co-owns the following patents: Methods to determine prognosis after therapy for prostate cancer. Granted 2002-09-06. Methods to determine prognosis after therapy for bladder cancer. Granted 2003-06-19. Prognostic methods for patients with prostatic disease. Granted 2004-08-05. Soluble Fas: urinary marker for the detection of bladder transitional cell carcinoma. Granted 2010-07-20. He is an advisory board member of Astellas, Cepheid, Ipsen, Jansen, Lilly, Olympus, Pfizer, Pierre Fabre, Sanofi, Wolff. He is the speaker for Astellas, Ipsen, Jansen, Lilly, Olympus, Pfizer, Pierre Fabre, Sanochemia, Sanofi, Wolff.

Ethical standards This study was conducted according to the Declaration of Helsinki.

Open Access This article is distributed under the terms of the Creative Commons Attribution 4.0 International License (http://creativeco mmons.org/licenses/by/4.0/), which permits unrestricted use, distribution, and reproduction in any medium, provided you give appropriate credit to the original author(s) and the source, provide a link to the Creative Commons license, and indicate if changes were made.

\section{References}

1. Leal J, Luengo-Fernandez R, Sullivan R, Witjes JA (2016) Economic burden of bladder cancer across the European union. Eur Urol 69:438-447. https://doi.org/10.1016/j.eururo.2015.10.024

2. Sievert KD, Amend B, Nagele U, Schilling D, Bedke J, Horstmann $\mathrm{M}$ et al (2009) Economic aspects of bladder cancer: what are the benefits and costs? World J Urol 27:295-300. https://doi. org/10.1007/s00345-009-0395-z

3. Babjuk M, Böhle A, Burger M, Capoun O, Cohen D, Compérat EM et al (2016) EAU Guidelines on Non-Muscle-invasive Urothelial Carcinoma of the Bladder: Update. Eur Urol 71:447461. https://doi.org/10.1016/j.eururo.2016.05.041 (n.d.)

4. Kamat AM, Hegarty PK, Gee JR, Clark PE, Svatek RS, Hegarty $\mathrm{N}$ et al (2013) ICUD-EAU international consultation on bladder cancer 2012: screening, diagnosis, and molecular markers. Eur Urol 63:4-15. https://doi.org/10.1016/j.eururo.2012.09.057

5. Messer J, Shariat SF, Brien JC, Herman MP, Ng CK, Scherr DS et al (2011) Urinary cytology has a poor performance for predicting invasive or high-grade upper-tract urothelial carcinoma. BJU Int 108:701-705. https://doi.org/10.1111/j.1464-410X.2010.09899.x

6. Karakiewicz PI, Benayoun S, Zippe C, Lüdecke G, Boman H, Sanchez-Carbayo M et al (2006) Institutional variability in the accuracy of urinary cytology for predicting recurrence of transitional cell carcinoma of the bladder. BJU Int 97:997-1001. https ://doi.org/10.1111/j.1464-410X.2006.06036.x

7. Lotan Y, O’Sullivan P, Raman JD, Shariat SF, Kavalieris L, Frampton $\mathrm{C}$ et al (2017) Clinical comparison of noninvasive urine tests for ruling out recurrent urothelial carcinoma. Urol Oncol Semin Orig Investig 35:531.e15-531.e22. https://doi. org/10.1016/j.urolonc.2017.03.008

8. Daneshmand S, Patel S, Lotan Y, Pohar K, Trabulsi E, Woods M et al (2017) Efficacy and safety of blue light flexible cystoscopy with hexaminolevulinate (HAL) in the surveillance of bladder cancer: a Phase III, comparative. Multi Center Study J Urol. https ://doi.org/10.1016/j.juro.2017.11.096

9. Tilki D, Burger M, Dalbagni G, Grossman HB, Hakenberg OW, Palou J et al (2011) Urine markers for detection and surveillance of non-muscle-invasive bladder cancer. Eur Urol 60:484-492. https://doi.org/10.1016/j.eururo.2011.05.053

10. Lawrentschuk $\mathbf{N}$ (2018) Evolution of technologies in urology: full steam ahead? World J Urol 36:517-518. https://doi.org/10.1007/ s00345-018-2246-2

11. Shariat SF, Lotan Y, Vickers A, Karakiewicz PI, Schmitz-Drager BJ, Goebell PJ et al (2010) Statistical consideration for clinical biomarker research in bladder cancer. Urol Oncol 28:389-400. https://doi.org/10.1016/j.urolonc.2010.02.011

12. Bensalah K, Montorsi F, Shariat SF (2007) Challenges of cancer biomarker profiling. Eur Urol 52:1601-1609. https://doi. org/10.1016/j.eururo.2007.09.036

13. Lotan Y, Shariat SF, Schmitz-Drager BJ, Sanchez-Carbayo M, Jankevicius F, Racioppi M et al (2010) Considerations on implementing diagnostic markers into clinical decision making in bladder cancer. Urol Oncol 28:441-448. https://doi.org/10.1016/j. urolonc.2009.11.004

14. Chang SS, Boorjian SA, Chou R, Clark PE, Daneshmand S, Konety BR et al (2016) Diagnosis and treatment of non-muscle invasive bladder cancer: AUA/SUO guideline. J Urol 196:10211029. https://doi.org/10.1016/j.juro.2016.06.049

15. Seideman C, Canter D, Kim P, Cordon B, Weizer A, Oliva I et al (2015) Multicenter evaluation of the role of UroVysion FISH assay in surveillance of patients with bladder cancer: does FISH positivity anticipate recurrence? World J Urol 33:1309-1313. https://doi.org/10.1007/s00345-014-1452-9

16. Mbeutcha A, Lucca I, Mathieu R, Lotan Y, Shariat SF (2016) Current status of urinary biomarkers for detection and surveillance of bladder cancer. Urol Clin North Am 43:47-62. https:// doi.org/10.1016/j.ucl.2015.08.005

17. Mowatt G, Zhu S, Kilonzo M, Boachie C, Fraser C, Griffiths T et al (2010) Systematic review of the clinical effectiveness and cost-effectiveness of photodynamic diagnosis and urine biomarkers (FISH, ImmunoCyt, NMP22) and cytology for the detection and follow-up of bladder cancer. Health Technol Assess (Rockv) 14:1-331. https://doi.org/10.3310/hta14040 (iii-iv)

18. Yafi FA, Brimo F, Steinberg J, Aprikian AG, Tanguay S, Kassouf W (2015) Prospective analysis of sensitivity and specificity of urinary cytology and other urinary biomarkers for bladder cancer. Urol Oncol Semin Orig Investig 33:66.e25-66.e31. https:// doi.org/10.1016/j.urolonc.2014.06.008

19. Bell MD, Yafi FA, Brimo F, Steinberg J, Aprikian AG, Tanguay $S$ et al (2016) Prognostic value of urinary cytology and other biomarkers for recurrence and progression in bladder cancer: a prospective study. World J Urol 34:1405-1409. https://doi. org/10.1007/s00345-016-1795-5 
20. Pichler R, Tulchiner G, Fritz J, Schaefer G, Horninger W, Heidegger I (2017) Urinary UBC Rapid and NMP22 Test for bladder cancer surveillance in comparison to urinary cytology: results from a prospective single-center study. Int J Med Sci 14:811819. https://doi.org/10.7150/ijms.19929

21. Shariat SF, Savage C, Chromecki TF, Sun M, Scherr DS, Lee RK et al (2011) Assessing the clinical benefit of nuclear matrix protein 22 in the surveillance of patients with nonmuscle-invasive bladder cancer and negative cytology: a decision-curve analysis. Cancer 117:2892-2897. https://doi.org/10.1002/cncr.25903

22. Shariat SF, Zippe C, Lüdecke G, Boman H, Sanchez-Carbayo M, Casella R et al (2005) Nomograms including nuclear matrix protein 22 for prediction of disease recurrence and progression in patients with Ta, T1 or CIS transitional cell carcinoma of the bladder. J Urol 173:1518-1525. https://doi.org/10.1097/01. ju.0000154696.48217.75

23. Babjuk M, Soukup V, Pešl M, Koštirrová M, Drncová E, Smolová $\mathrm{H}$ et al (2008) Urinary cytology and quantitative BTA and UBC tests in surveillance of patients with pTapT1 bladder urothelial carcinoma. Urology 71:718-722. https://doi.org/10.1016/j.urolo gy.2007.12.021

24. Raitanen M-P (2008) FinnBladder group. The role of BTA stat test in follow-up of patients with bladder cancer: results from FinnBladder studies. World J Urol 26:45-50. https://doi. org/10.1007/s00345-007-0230-3

25. Lokeshwar VB, Schroeder GL, Selzer MG, Hautmann SH, Posey JT, Duncan RC et al (2002) Bladder tumor markers for monitoring recurrence and screening comparison of hyaluronic acidhyaluronidase and BTA-Stat tests. Cancer 95:61-72. https://doi. org/10.1002/cncr.10652

26. Sarosdy MF, deVere White RW, Soloway MS, Sheinfeld J, Hudson MA, Schellhammer PF et al (1995) Results of a multicenter trial using the BTA test to monitor for and diagnose recurrent bladder cancer. J Urol 154:379-383 (discussion 383-4)

27. Cha EK, Tirsar LA, Schwentner C, Christos PJ, Mian C, Hennenlotter J et al (2012) Immunocytology is a strong predictor of bladder cancer presence in patients with painless hematuria: a multicentre study. Eur Urol 61:185-192. https://doi.org/10.1016/j. eururo.2011.08.073

28. Mian C, Maier K, Comploj E, Lodde M, Berner L, Lusuardi L et al (2006) uCyt $+/ \mathrm{ImmunoCyt}^{\mathrm{TM}}$ in the detection of recurrent urothelial carcinoma. Cancer 108:60-65. https://doi.org/10.1002/ cncr.21712

29. Lotan Y, Bensalah K, Ruddell T, Shariat SF, Sagalowsky AI, Ashfaq R (2008) Prospective evaluation of the clinical usefulness of reflex fluorescence in situ hybridization assay in patients with atypical cytology for the detection of urothelial carcinoma of the bladder. J Urol 179:2164-2169. https://doi.org/10.1016/j. juro.2008.01.105

30. Schlomer BJ, Ho R, Sagalowsky A, Ashfaq R, Lotan Y (2010) Prospective validation of the clinical usefulness of reflex fluorescence in situ hybridization assay in patients with atypical cytology for the detection of urothelial carcinoma of the bladder. $\mathrm{J}$ Urol 183:62-67. https://doi.org/10.1016/j.juro.2009.08.157

31. Chang SS, Boorjian SA, Chou R, Clark PE, Daneshmand S, Konety BR et al (2016) Diagnosis and treatment of non-muscle invasive bladder cancer: AUA/SUO guideline. J Urol 196:10211029. https://doi.org/10.1016/j.juro.2016.06.049

32. Kim PH, Sukhu R, Cordon BH, Sfakianos JP, Sjoberg DD, Hakimi AA et al (2014) Reflex fluorescence in situ hybridization assay for suspicious urinary cytology in patients with bladder cancer with negative surveillance cystoscopy. BJU Int 114:354359. https://doi.org/10.1111/bju.12516 (n/a-n/a)

33. Gayed BA, Seideman C, Lotan Y (2013) Cost-effectiveness of fluorescence in situ hybridization in patients with atypical cytology for the detection of urothelial carcinoma. J Urol 190:1181-1186. https://doi.org/10.1016/j.juro.2013.03.117

34. Kavalieris L, O'Sullivan P, Frampton C, Guilford P, Darling D, Jacobson E et al (2017) Performance Characteristics of a Multigene Urine Biomarker Test for Monitoring for Recurrent Urothelial Carcinoma in a Multicenter Study. J Urol 197:1419-1426. https://doi.org/10.1016/j.juro.2016.12.010

35. Pichler R, Fritz J, Tulchiner G, Klinglmair G, Soleiman A, Horninger $\mathrm{W}$ et al (2018) Increased accuracy of a novel mRNA-based urine test for bladder cancer surveillance. BJU Int 121:29-37. https://doi.org/10.1111/bju.14019

36. Svatek RS, Herman MP, Lotan Y, Casella R, Hsieh J-T, Sagalowsky AI et al (2006) Soluble fas-a promising novel urinary marker for the detection of recurrent superficial bladder cancer. Cancer 106:1701-1707. https://doi.org/10.1002/cncr.21795

37. Yang H, Li H, Wang Z, Gao J, Guo Y (2013) Is urinary soluble fas an independent predictor of non-muscle-invasive bladder cancer? A prospective chart study. Urol Int 91:456-461. https ://doi.org/10.1159/000350752

38. Kramer MW, Golshani R, Merseburger AS, Knapp J, Garcia A, Hennenlotter J et al (2010) HYAL-1 hyaluronidase: a potential prognostic indicator for progression to muscle invasion and recurrence in bladder cancer. Eur Urol 57:86-94. https://doi. org/10.1016/j.eururo.2009.03.057

39. Shariat SF, Casella R, Khoddami SM, Hernandez G, Sulser T, Gasser TC et al (2004) Urine detection of survivin is a sensitive marker for the noninvasive diagnosis of bladder cancer. J Urol 171:626-630. https://doi.org/10.1097/01.ju.0000107826 .78479 .90

40. Shariat SF, Ashfaq R, Karakiewicz PI, Saeedi O, Sagalowsky AI, Lotan Y (2007) Survivin expression is associated with bladder cancer presence, stage, progression, and mortality. Cancer 109:1106-1113. https://doi.org/10.1002/cncr.22521

41. Brems-Eskildsen AS, Zieger K, Toldbod H, Holcomb C, Higuchi R, Mansilla F et al (2010) Prediction and diagnosis of bladder cancer recurrence based on urinary content of hTERT, SENP1, PPP1CA, and MCM5 transcripts. BMC Cancer 10:646. https://doi.org/10.1186/1471-2407-10-646

42. Billerey C, Chopin D, Aubriot-Lorton MH, Ricol D, Diez Gil, de Medina S, Van Rhijn B et al (2001) Frequent FGFR3 mutations in papillary non-invasive bladder ( $\mathrm{pTa}$ ) tumors. Am J Pathol 158:1955-1959. https://doi.org/10.1016/S0002 -9440(10)64665-2

43. van Rhijn BW, Lurkin I, Radvanyi F, Kirkels WJ, van der Kwast TH, Zwarthoff EC (2001) The fibroblast growth factor receptor 3 (FGFR3) mutation is a strong indicator of superficial bladder cancer with low recurrence rate. Cancer Res 61:1265-1268

44. Zuiverloon TCM, van der Aa MNM, van der Kwast TH, Steyerberg EW, Lingsma HF, Bangma CH et al (2010) Fibroblast growth factor receptor 3 mutation analysis on voided urine for surveillance of patients with low-grade non-muscle-invasive bladder cancer. Clin Cancer Res 16:3011-3018. https://doi. org/10.1158/1078-0432.CCR-09-3013

45. Su S-F, de Castro Abreu AL, Chihara Y, Tsai Y, Andreu-Vieyra C, Daneshmand S et al (2014) A panel of three markers hyperand hypomethylated in urine sediments accurately predicts bladder cancer recurrence. Clin Cancer Res 20:1978-1989. https:// doi.org/10.1158/1078-0432.CCR-13-2637

46. Ho C-L, Tzai T-S, Chen J-C, Tsai H-W, Cheng H-L, Eisenberger $\mathrm{CF}$ et al (2008) the molecular signature for urothelial carcinoma of the upper urinary tract. J Urol 179:1155-1159. https://doi. org/10.1016/j.juro.2007.10.026

47. Maldonado L, Brait M, Michailidi C, Munari E, Driscoll T, Schultz L et al (2014) An epigenetic marker panel for recurrence risk prediction of low grade papillary urothelial cell carcinoma 
(LGPUCC) and its potential use for surveillance after transurethral resection using urine. Oncotarget 5:5218-5233. https://doi. org/10.18632/oncotarget.2129

48. Abern MR, Owusu R, Inman BA (2014) Clinical performance and utility of a DNA methylation urine test for bladder cancer11This study was funded, in part, by MDxHealth (formerly OncoMethlyome sciences). Urol Oncol Semin Orig Investig 32:51.e21-51.e26. https://doi.org/10.1016/j.urolonc.2013.08.003

49. Beukers W, van der Keur KA, Kandimalla R, Vergouwe Y, Steyerberg EW, Boormans JL et al (2017) FGFR3, TERT and OTX1 as a urinary biomarker combination for surveillance of patients with bladder cancer in a large prospective multicenter study. J Urol 197:1410-1418. https://doi.org/10.1016/j. juro.2016.12.096

50. Kandimalla R, Masius R, Beukers W, Bangma CH, Orntoft TF, Dyrskjot L et al (2013) A 3-plex methylation assay combined with the FGFR3 mutation assay sensitively detects recurrent bladder cancer in voided urine. Clin Cancer Res 19:4760-4769. https://doi.org/10.1158/1078-0432.CCR-12-3276

51. Roperch J-P, Grandchamp B, Desgrandchamps F, Mongiat-Artus P, Ravery V, Ouzaid I et al (2016) Promoter hypermethylation of HS3ST2, SEPTIN9 and SLIT2 combined with FGFR3 mutations as a sensitive/specific urinary assay for diagnosis and surveillance in patients with low or high-risk non-muscle-invasive bladder cancer. BMC Cancer 16:704. https://doi.org/10.1186/s1288 5-016-2748-5

52. Kumari N, Agrawal U, Mishra AK, Kumar A, Vasudeva P, Mohanty NK et al (2017) Predictive role of serum and urinary cytokines in invasion and recurrence of bladder cancer. Tumor Biol 39:101042831769755. https://doi.org/10.1177/1010428317 697552

53. van der Aa MNM, Zwarthoff EC, Steyerberg EW, Boogaard MW, Nijsen Y, van der Keur KA et al (2009) Microsatellite Analysis of voided-urine samples for surveillance of low-grade non-muscleinvasive urothelial carcinoma: feasibility and clinical utility in a prospective multicenter study [cost-effectiveness of follow-up of urinary bladder cancer trial (CEFUB)]. Eur Urol 55:659-668. https://doi.org/10.1016/j.eururo.2008.05.001

54. Margulis V, Shariat SF, Ashfaq R, Sagalowsky AI, Lotan Y (2006) Ki-67 is an independent predictor of bladder cancer outcome in patients treated with radical cystectomy for organconfined disease. Clin Cancer Res 12:7369-7373. https://doi. org/10.1158/1078-0432.CCR-06-1472

55. Kojima T, Kawai K, Miyazaki J, Nishiyama H (2017) Biomarkers for precision medicine in bladder cancer. Int J Clin Oncol 22:207-213. https://doi.org/10.1007/s10147-016-1068-8

56. Redelman-Sidi G, Glickman MS, Bochner BH (2014) The mechanism of action of BCG therapy for bladder cancer-a current perspective. Nat Rev Urol 11:153-162. https://doi.org/10.1038/ nrurol.2014.15

57. Savic S, Zlobec I, Thalmann GN, Engeler D, Schmauss M, Lehmann K et al (2009) The prognostic value of cytology and fluorescence in situ hybridization in the follow-up of nonmuscleinvasive bladder cancer after intravesical Bacillus Calmette-Guérin therapy. Int J Cancer 124:2899-2904. https://doi.org/10.1002/ ijc. 24258

58. Kamat AM, Willis DL, Dickstein RJ, Anderson R, NoguerasGonzález G, Katz RL et al (2016) Novel fluorescence in situ hybridization-based definition of Bacille Calmette-Guérin (BCG) failure for use in enhancing recruitment into clinical trials of intravesical therapies. BJU Int 117:754-760. https://doi. org/10.1111/bju.13186

59. Kamat AM, Briggman J, Urbauer DL, Svatek R, Nogueras González GM, Anderson R et al (2016) Cytokine panel for response to intravesical therapy (CyPRIT): nomogram of changes in urinary cytokine levels predicts patient response to
Bacillus Calmette-Guérin. Eur Urol 69:197-200. https://doi. org/10.1016/j.eururo.2015.06.023

60. Saint F, Patard JJ, Maille P, Soyeux P, Hoznek A, Salomon L et al (2002) Prognostic value of a T helper 1 urinary cytokine response after intravesical Bacillus Calmette-Guerin treatment for superficial bladder cancer. J Urol 167:364-367

61. Watanabe E, Matsuyama H, Matsuda K, Ohmi C, Tei Y, Yoshihiro $S$ et al (2003) Urinary interleukin-2 may predict clinical outcome of intravesical Bacillus Calmette-Guérin immunotherapy for carcinoma in situ of the bladder. Cancer Immunol Immunother 52:481-486. https://doi.org/10.1007/s00262-003-0384-9

62. de Reijke TM, de Boer EC, Kurth KH, Schamhart DH (1996) Urinary cytokines during intravesical Bacillus Calmette-Guerin therapy for superficial bladder cancer: processing, stability and prognostic value. J Urol 155:477-482

63. Thalmann GN, Sermier A, Rentsch C, Möhrle K, Cecchini MG, Studer UE (2000) Urinary Interleukin-8 and 18 predict the response of superficial bladder cancer to intravesical therapy with Bacillus Calmette-Guerin. J Urol 164:2129-2133

64. Sagnak L, Ersoy H, Ozok U, Senturk B, Ercil H, Bahar G et al (2009) Predictive value of urinary interleukin- 8 cutoff point for recurrences after transurethral resection plus induction Bacillus Calmette-Guérin treatment in non-muscle-invasive bladder tumors. Clin Genitourin Cancer 7:E16-E23. https://doi. org/10.3816/CGC.2009.n.016

65. Cai T, Nesi G, Mazzoli S, Meacci F, Tinacci G, Luciani LG et al (2012) Prediction of response to Bacillus Calmette-Guérin treatment in non-muscle invasive bladder cancer patients through interleukin-6 and interleukin-10 ratio. Exp Ther Med 4:459-464. https://doi.org/10.3892/etm.2012.634

66. Aguilera Tubet C, Gutiérrez Baños JL, Antolín Juárez F, Rebollo Rodrigo MH, Portillo Martín JA, Ruiz Izquierdo F et al (2005) Comparative study between cystoscopy, urinary cytology, NMP22 and a new method, bladder chek, in the follow-up of superficial bladder cell carcinoma. Actas Urol Esp 29:252-256

67. Grossman HB, Soloway M, Messing E, Katz G, Stein B, Kassabian V et al (2006) Surveillance for recurrent bladder cancer using a point-of-care proteomic assay. JAMA 295:299. https:// doi.org/10.1001/jama.295.3.299

68. Kumar A, Kumar R, Gupta NP (2006) Comparison of NMP22 bladder chek test and urine cytology for the detection of recurrent bladder cancer. Jpn J Clin Oncol 36:172-175. https://doi. org/10.1093/jjco/hyi244

69. Gonzalo Rodríguez V, Sanz Justo L, de Miguel Santamaría I, Martínez de Iturrate J, Fernández del Busto E (2008) The use of NMP22 Bladder-Chek for the diagnosis and follow-up bladder cancer. Arch Esp Urol 61:377-384

70. Gupta NP, Sharma N, Kumar R (2009) Nuclear matrix protein 22 as adjunct to urine cytology and cystoscopy in follow-up of superficial TCC of urinary bladder. Urology 73:592-596. https ://doi.org/10.1016/j.urology.2008.04.051

71. Kundal VK, Pandith AA, Hamid A, Shah A, Kundal R, Wani SM (2010) Role of NMP22 bladder check test in early detection of bladder cancer with recurrence. Asian Pac J Cancer Prev 11:1279-1282

72. Choi HS, Lee SI, Kim DJ, Jeong TY (2010) Usefulness of the NMP22BladderChek test for screening and follow-up of bladder cancer. Korean J Urol 51:88. https://doi.org/10.4111/ kju.2010.51.2.88

73. Hwang EC, Choi HS, Jung S Il, Kwon DD, Park K, Ryu SB (2011) Use of the NMP22 BladderChek test in the diagnosis and follow-up of urothelial cancer: a cross-sectional study. Urology 77:154-159. https://doi.org/10.1016/j.urology.2010.04.059

74. Coskuner E, Cevik I, Ozkan A, Dillioglugil O, Akdas A (2012) In the cystoscopic follow-up of non-muscle-invasive transitional cell carcinoma, NMP-22 works for high grades, but unreliable 
in low grades and upper urinary tract tumors. Int Urol Nephrol 44:793-798. https://doi.org/10.1007/s11255-012-0144-x

75. Önal B, Han Ü, Yilmaz S, Köybasioglu F, Altuğ U (2015) The use of urinary nuclear matrix protein 22 (NMP22) as a diagnostic adjunct to urine cytology for monitoring of recurrent bladder cancer-institutional experience and review. Diagn Cytopathol 43:307-314. https://doi.org/10.1002/dc.23239

76. Serretta V, Lo Presti D, Vasile P, Gange E, Esposito E, Menozzi I (1998) Urinary NMP22 for the detection of recurrence after transurethral resection of transitional cell carcinoma of the bladder: experience on 137 patients. Urology 52:793-796

77. Witjes JA, van der Poel HG, van Balken MR, Debruyne FM, Schalken JA (1998) Urinary NMP22 and karyometry in the diagnosis and follow-up of patients with superficial bladder cancer. Eur Urol 33:387-391

78. Serretta V, Pomara G, Rizzo I, Esposito E (2000) Urinary BTAstat, BTA-trak and NMP22 in surveillance after TUR of recurrent superficial transitional cell carcinoma of the bladder. Eur Urol 38:419-425 (doi:20318)

79. Chahal R, Darshane A, Browning AJ, Sundaram SK (2001) Evaluation of the clinical value of urinary NMP22 as a marker in the screening and surveillance of transitional cell carcinoma of the urinary bladder. Eur Urol 40:415-420 (discussion 421)

80. Giannopoulos A, Manousakas T, Gounari A, Constantinides C, Choremi-Papadopoulou H, Dimopoulos C (2001) Comparative evaluation of the diagnostic performance of the BTA stat test, NMP22 and urinary bladder cancer antigen for primary and recurrent bladder tumors. J Urol 166:470-475

81. Shariat SF, Casella R, Wians FH, Ashfaq R, Balko J, Sulser T et al (2004) Risk stratification for bladder tumor recurrence, stage and grade by urinary nuclear matrix protein 22 and cytology. Eur Urol 45:304-313. https://doi.org/10.1016/j.eururo.2003.10.020

82. Lahme S, Bichler K-H, Feil G, Zumbrägel A, Götz T (2003) Comparison of cytology and nuclear matrix protein 22 (NMP 22) for the detection and follow-up of bladder-cancer. Adv Exp Med Biol 539:111-119

83. Kibar Y, Goktas S, Kilic S, Yaman H, Onguru O, Peker AF (2006) Prognostic value of cytology, nuclear matrix protein 22 (NMP22) test, and urinary bladder cancer II (UBC II) test in early recurrent transitional cell carcinoma of the bladder. Ann Clin Lab Sci 36:31-38

84. Raina R, Pahlajani G, Ponsky LE, Agarwal A, Zippe CD (2008) The clinical utility of atypical cytology is significantly increased in both screening and monitoring for bladder cancer when indexed with nuclear matrix protein-22. BJU Int 102:297-300. https://doi.org/10.1111/j.1464-410X.2008.07789.x

85. Mansoor I, Calam RR, Al-Khafaji B (2008) Role of urinary NMP-22 combined with urine cytology in follow-up surveillance of recurring superficial bladder urothelial carcinoma. Anal Quant Cytol Histol 30:25-32

86. Horstmann M, Patschan O, Hennenlotter J, Senger E, Feil G, Stenzl A (2009) Combinations of urine-based tumour markers in bladder cancer surveillance. Scand J Urol Nephrol 43:461-466. https://doi.org/10.3109/00365590903296837

87. Dogan C, Pelit ES, Yildirim A, Ebru Zemheri I, Canakci C, Kaan Başok E et al (2014) The value of the NMP22 test for superficial bladder cancer diagnosis and follow-up. Türk Üroloji Dergisi/ Turkish J Urol 39:137-142. https://doi.org/10.5152/tud.2013.029

88. Ianari A, Sternberg CN, Rossetti A, Van Rijn A, Deidda A, Giannarelli D et al (1997) Results of Bard BTA test in monitoring patients with a history of transitional cell cancer of the bladder. Urology 49:786-789. https://doi.org/10.1016/S0090 $-4295(97) 00081-2$
89. Leyh H, Mazeman E (1997) Bard BTA test compared with voided urine cytology in the diagnosis of recurrent bladder cancer. Eur Urol 32:425-428

90. Kirollos MM (1997) The use of the bladder-tumour associated analyte test to determine the type of cystoscopy in the follow-up of patients with bladder cancer. The United Kingdom and Eire Bladder tumour antigen study group. Br J Urol 79:362-366

91. Sarosdy MF, Hudson MA, Ellis WJ, Soloway MS, deVere White $\mathrm{R}$, Sheinfeld J et al (1997) Improved detection of recurrent bladder cancer using the bard BTA stat test. Urology 50:349-353

92. Sarosdy MF, Schellhammer P, Bokinsky G, Kahn P, Chao R, Yore L et al (2002) Clinical evaluation of a multi-target fluorescent in situ hybridization assay for detection of bladder cancer. J Urol 168:1950-1954. https://doi.org/10.1097/01.ju.0000034254 $89258.8 \mathrm{e}$

93. Gutiérrez Baños JL, Martín García B, de Diego Rodríguez E, Hernández Rodríguez R, Portillo Martín JA, Correas Gómez MA et al (1999) The BTA stat test in the follow-up for bladder cancer. Arch Esp Urol 52:856-861

94. Fernández Gómez JM, García Rodríguez J, Escaf Barmadah S, Raigoso P, Rodríguez Martínez JJ, Allende MT et al (2002) Urinary BTA-TRAK in the follow-up of superficial transitional-cell bladder carcinoma. Arch Esp Urol 55:41-49 (n.d.)

95. Vriesema JL, Atsma F, Kiemeney LA, Peelen WP, Witjes JA, Schalken JA (2001) Diagnostic efficacy of the ImmunoCyt test to detect superficial bladder cancer recurrence. Urology 58:367-371

96. Pfister C, Chautard D, Devonec M, Perrin P, Chopin D, Rischmann P et al (2003) Immunocyt test improves the diagnostic accuracy of urinary cytology: results of a French multicenter study. J Urol 169:921-924. https://doi.org/10.1097/01.ju.00000 48983.83079.4c

97. Têtu B, Tiguert R, Harel F, Fradet Y (2005) ImmunoCyt/ $\mathrm{uCyt}+{ }^{\mathrm{TM}}$ improves the sensitivity of urine cytology in patients followed for urothelial carcinoma. Mod Pathol 18:83-89. https ://doi.org/10.1038/modpathol.3800262

98. Messing EM, Teot L, Korman H, Underhill E, Barker E, Stork B et al (2005) Performance of urine test in patients monitored for recurrence of bladder cancer: a multicenter study in the United States. J Urol 174:1238-1241

99. Lodde M, Mian C, Comploj E, Palermo S, Longhi E, Marberger $\mathrm{M}$ et al (2006) uCyt + test: alternative to cystoscopy for lessinvasive follow-up of patients with low risk of urothelial carcinoma. Urology 67:950-954. https://doi.org/10.1016/j.urolo gy.2005.11.057

100. Sullivan PS, Nooraie F, Sanchez H, Hirschowitz S, Levin M, Rao PN et al (2009) Comparison of ImmunoCyt, UroVysion, and urine cytology in detection of recurrent urothelial carcinoma. Cancer Cytopathol 117:167-173. https://doi.org/10.1002/ cncy. 20026

101. Varella-Garcia M, Akduman B, Sunpaweravong P, Di Maria MV, Crawford ED (2004) The UroVysion fluorescence in situ hybridization assay is an effective tool for monitoring recurrence of bladder cancer. Urol Oncol Semin Orig Investig 22:16-19. https ://doi.org/10.1016/S1078-1439(03)00098-X

102. Pycha A, Lodde M, Comploj E, Negri G, Egarter-Vigl E, Vittadello $\mathrm{F}$ et al (2004) Intermediate-risk urothelial carcinoma: an unresolved problem? Urology 63:472-475. https://doi. org/10.1016/j.urology.2003.10.020

103. Kipp B, Karnes R, Brankley S, Harwood A, Pankratz V, Sebo $T$ et al (2005) Monitoring intravesical therapy for superficial bladder cancer using fluorescence in situ hybridization. J Urol 173:401-404. https://doi.org/10.1097/01.ju.0000149825.83180 .a4 
104. Bergman J, Reznichek RC, Rajfer J (2007) Surveillance of patients with bladder carcinoma using fluorescent in situ hybridization on bladder washings. BJU Int 0:070915222359021. https ://doi.org/10.1111/j.1464-410x.2007.07183.x

105. Moonen PMJ, Merkx GFM, Peelen P, Karthaus HFM, Smeets DFCM, Witjes JA (2007) UroVysion compared with cytology and quantitative cytology in the surveillance of non-muscleinvasive bladder cancer. Eur Urol 51:1275-1280. https://doi. org/10.1016/j.eururo.2006.10.044 (discussion 1280)

106. Yoder BJ, Skacel M, Hedgepeth R, Babineau D, Ulchaker JC, Liou LS et al (2007) Reflex UroVysion testing of bladder cancer surveillance patients with equivocal or negative urine cytology. Am J Clin Pathol 127:295-301. https://doi.org/10.1309/ADJL7 E810U1H42BJ

107. Gudjónsson S, Isfoss BL, Hansson K, Domanski A-M, Warenholt J, Soller W et al (2008) The value of the UroVysion ${ }^{\circledR}$ assay for surveillance of non-muscle-invasive bladder cancer. Eur Urol 54:402-408. https://doi.org/10.1016/j.eururo.2007.11.051
108. Karnwal A, Venegas R, Shuch B, Bassett J, Rajfer J, Reznichek $R$ (2010) The role of fluorescence in situ hybridization assay for surveillance of non-muscle invasive bladder cancer. Can J Urol 17:5077-5081

109. Fritsche H-M, Burger M, Dietmaier W, Denzinger S, Bach E, Otto W et al (2010) Multicolor FISH (UroVysion) facilitates follow-up of patients with high-grade urothelial carcinoma of the bladder. Am J Clin Pathol 134:597-603. https://doi.org/10.1309/ AJCPKKWBDSAOZ4RW

110. Youssef RF, Schlomer BJ, Ho R, Sagalowsky AI, Ashfaq R, Lotan Y (2012) Role of fluorescence in situ hybridization in bladder cancer surveillance of patients with negative cytology. Urol Oncol Semin Orig Investig 30:273-277. https://doi. org/10.1016/j.urolonc.2010.02.012 